second subpetiolate, sparsely hairy; third petiolate, hairy, with ten distal subsegments, the penultimate one laterally dilated; terminal segment lanceolate, without subsegments. Legs long, slender; tibia with broad alternate light and dark bands. Superior claw long, slender, little curved, obscurely toothed; inner edge sinuate basally, toothed in the middle and obscurely beyond; two obscure teeth on either side near the outer edge, dividing it into thirds; inferior claw two-thirds as long, stout, tapering, with a short bristle inside upon a rounded basal dilation and with a subapical bristle exceeding the other claw; tenent hairs absent. Furcula nearly reaching the mouth; manubrium with a few ventral hairs; dentes tapering, with remarkably long and large lateral hairs barbellate basally, and four longer equidistant ventral hairs; mucrones one fourth dentes, laterally linear, little-tapering, serrulate beneath, apex with three rounded lobes bent downward.

Length, I.3 mm. Waco, Texas (Belfrage).

Smynthurus packardii, n. sp. Body subtriangular, dilated broadly behind; pale luteous or brown, spotted with black dots, sometimes coalescing; a broad pale unspotted area on the anterior dorsum and another between the antennae and down the face; a light line along the middle of clypeus. Head, body and legs well covered with long, curving, white hairs, which on the vertex arise from black dots. Eyes conspicuously black. Antennae long, nearly equalling body; segments not tapering or knotted; as $\mathrm{I}: 2$ : $4: 8.5$; basal segment stout cylindrical, twice as long as broad, almost naked; second and third with hairs of irregular length; terminal segment with at least twenty distinct, whorled, globular subsegments. Superior claw narrowly lanceolate with slender, well-curved tip and a single tooth on the middle of the inside. Inferior claw two-thirds as long, lanceolate, nearly straight, with a short bristle inside, one-third from the base, upon a gradual dilation, also a subapical bristle not exceeding the other claw; tenent hairs absent. Furcula stout, extending beyond ventral tube; manubrium exceeding anal tubercle; dentes with moderately long lateral hairs and a single, long, ventral, subapical hair; mucrones stout, one third dentes in length, with straight dorsal outline, ventral edges irregularly undulate, and apex obliquely truncate.

Length. I.75 mm. Waco, Texas (Belfrage). In having over twenty antennal subseg. ments, $S$. packardii is unapproached by any American Smynthurus as yet described, with the possible exception of $S$. eisenii Schött, from California,* the two species being closely allied.

\title{
THE LARVA OF CAUTETHIA GROTEI HY. EDW.
}

\section{BY HARRISON G. DYAR, NEW YORK.}

Larvae solitary, sitting on a small stem of the food plant, the feet on joints 7 and 8 not used in rest. Head retractile at apex; the body widens to joint 5 , then gently tapers to tail; joints 12 and 13 are both small, the side angles of hind feet triangular projecting beyond anal plate. Horn long, slender, arising from an enlarged base. Annulets fine, distinct, with numerous secondary setae which are situated in paler spots, scarcely at all elevated into granules. A continuous subdorsal line runs from the middle of joint 2 to the horn, white, shading below into the side color, more or less pale yellow at its

* Schött, Harald. Beit. z. Kent. Kalif. Collem. Bih. Kongl. Svensk. Vet. Akad. Handl. Bd. I7, Afd. iv. No. 8 , p. 7 , Taf. I. fig. $1-6 . \quad$ I $89 x$. 
sharp upper border. Dorsal space light leaf green, an irregular, but distinct geminate, shaded greenish white dorsal band, broadening out and filling in all the dorsal space on joints 2 to 4 , still obscurely darker centered. All the space below the subdorsal line likewise completely filled in with the same greenish white, with the paler secondary dots. Spiracles white with a median brick red band, except the one on joint 5 which is white with a black spot at its posterior side. The side color of the body is cut by darker green oblique shades which run from the posterior edge of each segment on the substigmatal line upward and forward (in the reverse direction from what is usual in Sphingidae) each confined to a single segment, on joints 5 to II. A substigmatal line is distinct from the anal feet forward to joint II, white and yellow like the subdorsal line and also shaded with pink. Forward of joint II it becomes faint and is scarcely distinguishable in front of joint 8 . Horn pointed, green, with black spinules, the apex pale. Head dark green with narrow, obscure, vertical, pale bands; antennae pinkish; width about $2.5 \mathrm{~mm}$.; length of horn $4 \mathrm{~mm}$.; of the larva $28 \mathrm{~mm}$. The food plant of this tiny Sphinx is the "wax berry," Chiococca racemosa, determined for me by Mr. F. Kinzel. The imago appeared in six weeks. Larvae from Lake Worth, Florida.

\section{THE NEW CATAlogue OF BEes.}

Catalogus Hymenopterorum, Vol. X, Apidae (Anthophila). By Dr. C. G. De Dalla Torre, I896, pp. 643 .

All students of bees must gratefully welcome this admirable catalogue, which gives not only the names of the species, but the localities and all the more important references. It is practically complete up to the end of 1893 , but various species described in 1894 from America are omitted, though one would suppose that there might have been time to include them before print- ing. Of course, as is inevitable in such a work, the details suggest much criticism and comment. Very strangely, Wm. Kirby is in many places called W. F. Kirby, although the latter name is rightly the property of a much more recent entomologist, still happily with us. Andrena is modified to Anthrena, and Heriades to Eriades, but it is questionable whether such changes can be accepted. Anthophora becomes Podalirius, apparently on good grounds of priority. Our Colletes punctata Rob. (nom. preocc.) becomes $C$. robertsonii D. T. Our Halictus cephalicus Rob. (nom. preocc.) becomes $H$. cephalotes D.T., although there was already a nomen nudum H. cephalotes Schill., 1839. H. distinctus Prov. (preocc.) becomes distinguendus D. T. H. gracilis Rob. (preocc.) is altered to gracillimus, but Mr. Robertson had already changed the name to foxii. $H$. palustris Rob. is also altered to paludicola, in ignorance of Mr. Robertson's substitution of nymphaearum last year. $H$. constrictus Prov. (preocc.) becomes provancheri $\mathrm{D}$. $\mathrm{T}$. It may here be observed that $\mathrm{Mr}$. Robertson substituted $H$. macoupinensis for his $H$. quadrimaculatus, " nec Schenk"; but it appears that Schenck's species is a synonym of $H$. interruptus. Our H. fulvipes Sin. (preocc.) becomes rhododactylus D. T.

Our Andrena fimbriata Sm. (preocc.) becomes americana $\mathrm{D}$. T. $A$. simulata Prov. is altered to canadensis. A. clypeata Sm. becomes clypeolata D. T. $A$. laticeps Prov. becomes prouancheri. A. serotina Rob. becomes robertsonii. A. salicis Rob. was preoccupied by salicis Verhoeff; but the latter name is a synonym of albicans. A. scutellaris Rob. becomes scutellata D. T. Nomia punctata Fox (preocc.) is altered to $N$. foxii D. T.

Eunomia is not held to be distinct from Nomia. Cilissa is made a synonym of Mellitta. Eucera is made to include, as subgenera, Diadasia, Emphor, Melissodes, 

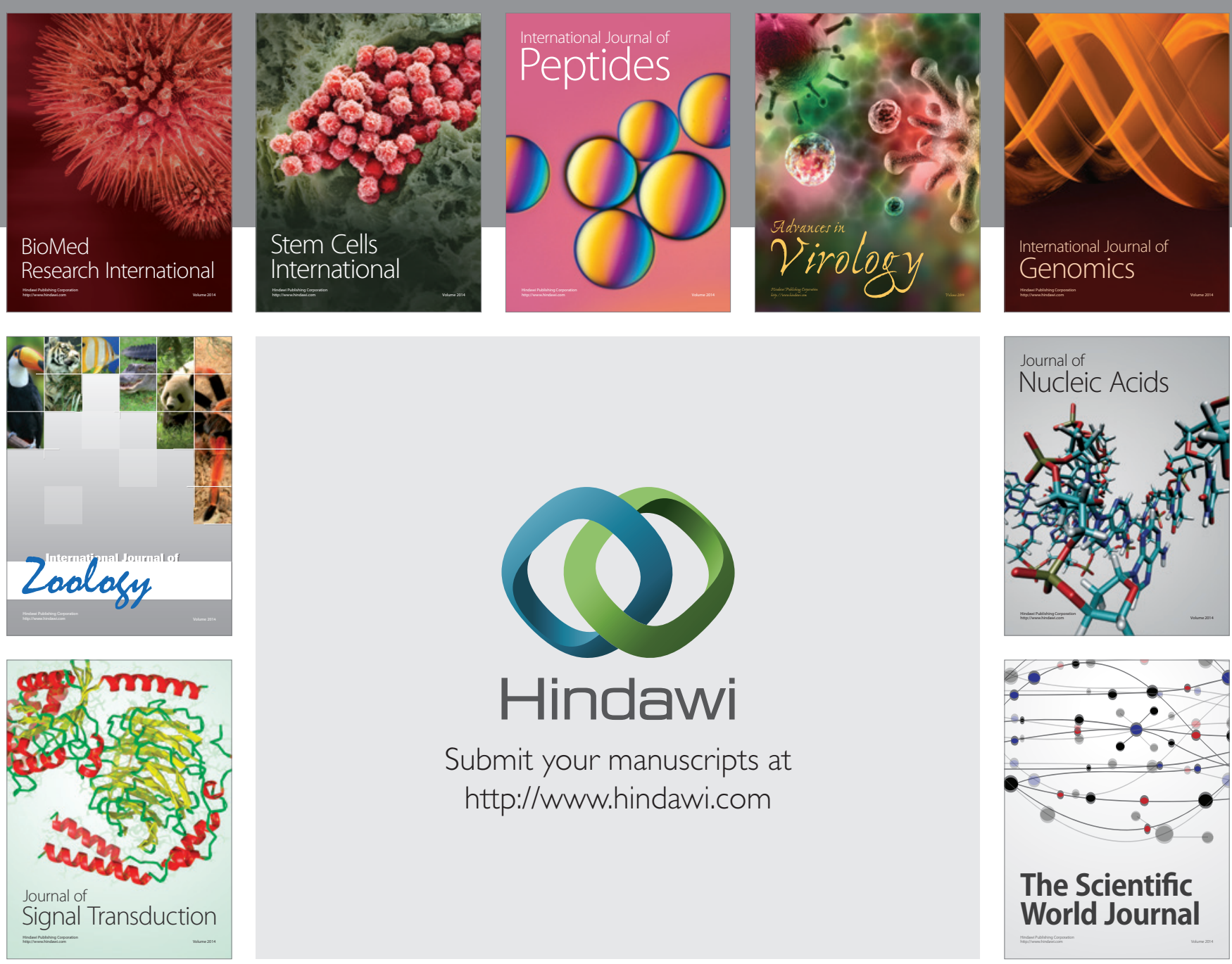

Submit your manuscripts at

http://www.hindawi.com
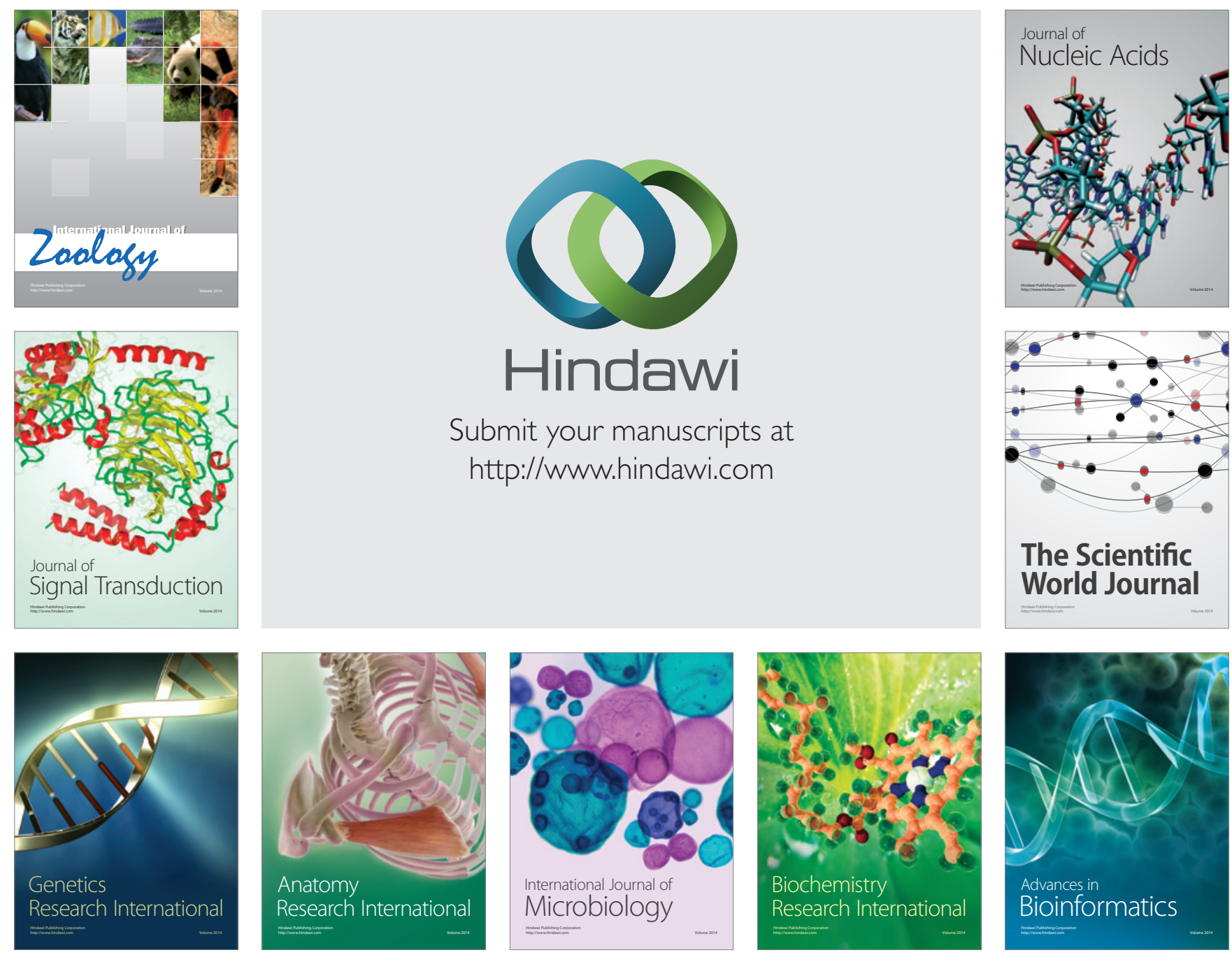

The Scientific World Journal
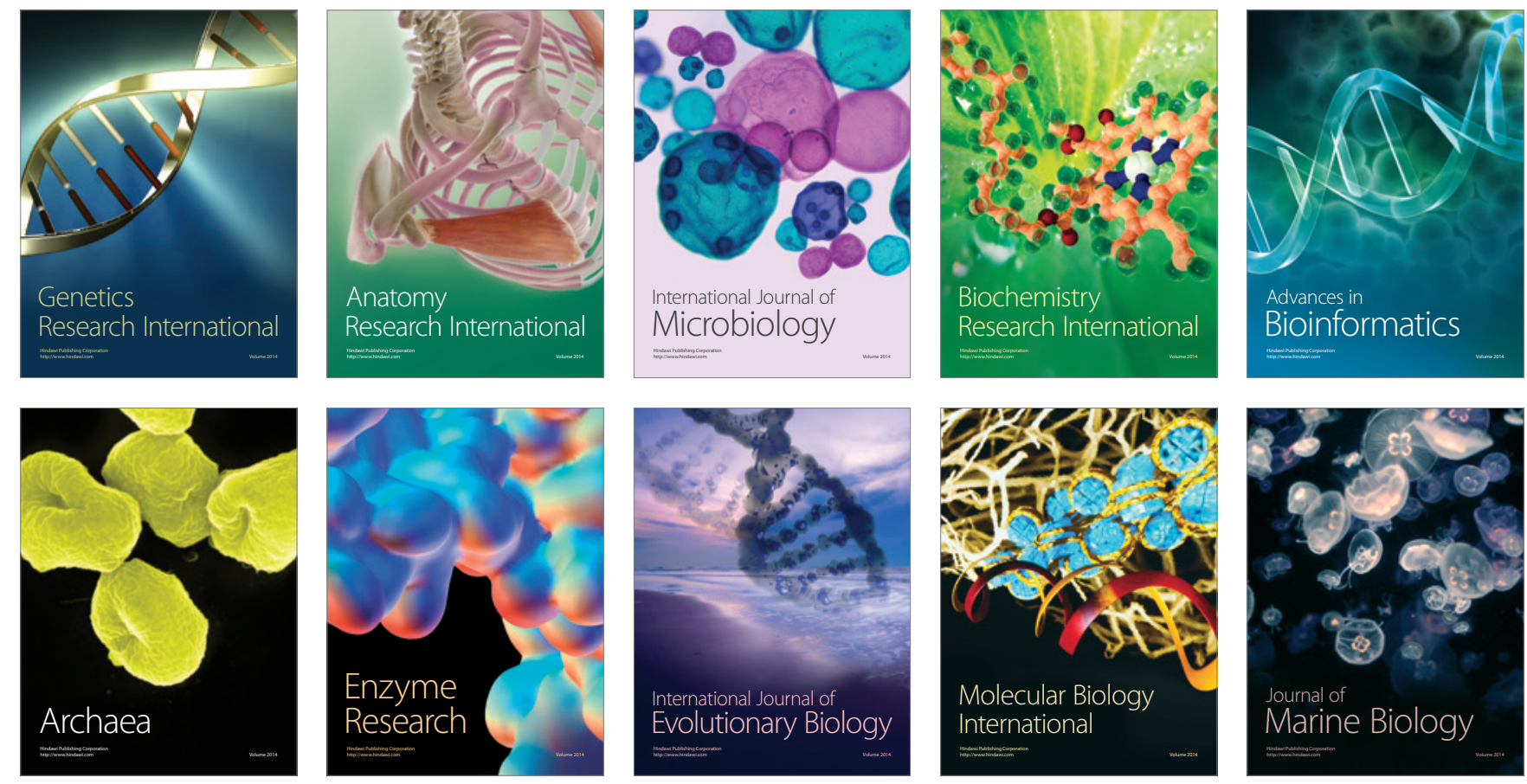